NBER WORKING PAPER SERIES

\title{
HOW DO LEGAL DIFFERENCES AND LEARNING AFFECT FINANCIAL CONTRACTS?
}

\author{
Steven Kaplan \\ Frederic Martel \\ Per Stromberg \\ Working Paper 10097 \\ http://www.nber.org/papers/w10097 \\ NATIONAL BUREAU OF ECONOMIC RESEARCH \\ 1050 Massachusetts Avenue \\ Cambridge, MA 02138 \\ November 2003
}

This research has been supported by the Kauffman Foundation, by the Lynde and Harry Bradley Foundation and the Olin Foundation through grants to the Center for the Study of the Economy and the State, and by the Center For Research in Security Prices. Ola Bengtsson, Alejandro Hajdenberg, Jonas Lindström, and Dali Ma provided excellent research assistance. We are grateful to the venture capital partnerships for providing data. We have received useful comments from Jim Brander, Ron Giammarino, Lucy White and seminar participants at the SIFR Conference on Venture Capital and University of British Columbia. Contact information: Steven Kaplan, Per Strömberg: University of Chicago Graduate School of Business, 1101 East 58th Street, Chicago, IL 60637; e-mail: skaplan@uchicago.edu, per.stromberg@gsb.uchicago.edu. Frederic Martel: UBS Global Asset Management, Gessnerallee 3-5, CH-8005 Zurich; IMD; and University of Lausanne; e-mail: frederic.martel@ubs.com. The views expressed herein are those of the authors and not necessarily those of the National Bureau of Economic Research.

(C2003 by Steven Kaplan, Frederic Martel, and Per Stromberg. All rights reserved. Short sections of text, not to exceed two paragraphs, may be quoted without explicit permission provided that full credit, including (C) notice, is given to the source. 
How Do Legal Differences and Learning Affect Financial Contracts?

Steven Kaplan, Frederic Martel, and Per Stromberg

NBER Working Paper No. 10096

November 2003

JEL No. G24, G32

\section{ABSTRACT}

We analyze venture capital (VC) investments in twenty-three non-U.S. countries and compare them to $\mathrm{VC}$ investments in the U.S. We describe how the contracts allocate cash flow, board, liquidation, and other control rights. In univariate analyses, contracts differ across legal regimes. At the same time, however, more experienced VCs implement U.S.-style contracts regardless of legal regime. In most specifications, legal regime becomes insignificant controlling for VC sophistication. VCs who use U.S.-style contracts fail significantly less often. Financial contracting theories in the presence of fixed costs of learning, therefore, appear to explain contracts along a wide range of legal regimes.

Steven N. Kaplan

Graduate School of Business

The University of Chicago

1101 East 58th Street

Chicago, IL 60637

and NBER

skaplan@uchicago.edu

Frederic Martel

University of Lausanne IMD

and UBS Global Asset Management

frederic.martel@ubs.com

Per Stromberg

Graduate School of Business

University of Chicago

1101 East 58th Street

Chicago, IL 60637

and NBER

per.stromberg@ghsb.uchicago.edu 


\section{Introduction}

Financial contracting plays an important role in aligning incentives and mitigating agency conflicts between investors and entrepreneurs, thus allowing new ventures to obtain financing. ${ }^{1}$ Studies of U.S. venture capital (VC) investing, such as Sahlman (1990) and Kaplan and Strömberg (2003 and 2004), show that investor contracts carefully allocate cash flow rights, liquidation rights, and control rights between the entrepreneur and the $\mathrm{VC}$ investor in order to mitigate agency conflicts. Kaplan and Stromberg (2003 and 2004) also show that the characteristics of U.S. VC contracts correspond well to the (optimal) contracts predicted by financial contracting theories.

At the same time, the large and growing literature in law and finance finds that legal and institutional differences among countries appear to be important for the development and nature of financial markets, and also for economic growth. ${ }^{2}$ The ability to design investments and financial contracts is potentially dependent on various elements of the institutional environment - the nature of corporate and contract law, the quality of legal enforcement, accounting systems, tax regulations, financial markets, etc. If the institutional environment affects the types of contracts that can be written, this could change the types of contracts that are optimal.

This raises the question of whether the financial contracts observed in the U.S. are optimal in other institutional environments. Theories of financial contracting would suggest yes (because they assume property rights are enforced and little else). Alternatively, sufficiently great institutional differences might lead to a negative answer. In this paper, we address this question by studying VC investments across different institutional environments - 145

\footnotetext{
${ }^{1}$ See Hart (2001).

${ }^{2}$ See King and Levine (1993), Laporta et al. (1997, 1998, and 2000), and Rajan and Zingales (2003).
} 
investments in 107 companies in 23 countries by 70 different lead VCs. The sample companies are concentrated in Western European countries and other relatively "developed" countries.

First, we describe how the contracts allocate cash flow, board, liquidation, and other control rights. In univariate analyses, the contracts differ significantly across legal regimes. While convertible preferred is the most commonly used security, it is used much less frequently outside the U.S. than in the U.S. Partly as a result, VCs investing outside the U.S. deals have weaker liquidation and exit rights. Non-U.S. investments also are less likely to use contingencies - including milestones, vesting provisions and anti-dilution rights - resulting in less high-powered cash flow incentives compared to their US counterparts.

Next, we consider how the contracts vary across legal regimes. We find that the contracts vary systematically across those regimes. In particular, investments in common law countries are more likely to look like U.S. contracts while investments elsewhere are likely to differ. Liquidation preferences, anti-dilution protections, vesting provisions and redemption rights are more typical in common law countries while milestones are less common. These results are similar to those found in Lerner and Schoar (2003) who study VC and private equity investments in developing countries.

Although contractual differences correlate with the institutional environment, they cannot fully explain these differences. For example, investors can implement seniority clauses, antidilution protection, redemption rights and vesting in non-common law countries like Germany, France, and Sweden. In fact, we find that some VC funds implement U.S. contractual features in those countries and across all the institutional environments in which they invest. In univariate analyses, as VC size, VC age, and VC experience with U.S. VCs increase, VCs are more likely to implement U.S. style contractual terms. This suggests that while it may not be easy or 
obvious how to adapt contracts, with enough effort (or legal fees), VCs can replicate most U.S.style contracts.

This leads us to compare the importance of legal regime versus learning and experience. We estimate the determinants of contracts using regressions that include both legal variables and measures of VC "sophistication." We find that U.S.-style contracts are more likely when the lead VC has previously syndicated with U.S. VCs, when the lead VC is from the U.S., and when the $\mathrm{VC}$ is larger and older. In the presence of the VC sophistication variables, institutional differences are relatively less important. The legal variables are not significant in most specifications.

The results on VC sophistication suggest that the U.S. model and U.S. contracts may be optimal outside the U.S. We explore this possibility by studying the survival of the $70 \mathrm{VCs}$ represented as lead investors in our sample. As of August 2003, 59 of the 70 are still active while 11 have not survived. We then separate the VC funds depending on the securities they used when acting as lead investors. None of the 37 funds that exclusively used convertible preferred (and U.S. style contracts) has failed. In contrast, $34 \%$ of the 29 funds that exclusively used common stock (and non-U.S. style contracts) have not survived. Said another way, of the 11 funds that have not survived, all but one never used convertible preferred. While this does not prove causality, the result strongly suggests that better funds use U.S. style contracts.

Overall, then, we interpret our results as being most consistent with an explanation in which financial contracting theories in the presence of fixed costs of learning appear to explain contracts along a wide range of legal regimes. Based on this, we would predict more convergence in contracts over time. 
Ours is not the first paper to study VC contracts outside of the U.S. ${ }^{3}$ Unlike this paper, however, most previous studies focus on a single country and do not compare contracts across institutional environments. Also, most of the studies do not analyze the actual contracts, but, instead, rely on survey evidence and self-reporting from VC firms. This is problematic because the studies critically depend on the details of the survey design and template. For example, as Kaplan and Strömberg (2003) demonstrate, securities with different names can implement identical allocations of cash flow and control rights (such as convertible preferred vs. "senior" common stock), while securities with the same name can differ substantially in their rights (e.g. standard vs. participating preferred stock).

In contrast to earlier studies, but similar to ours, contemporaneous work by Lerner and Schoar (2003) uses actual contracts in private equity investments in developing countries. We view their sample and paper as an interesting complement to ours. They find similar results in that contracts are significantly related to legal origin. While they do not focus on the sophistication and learning effects that we consider, their results on legal origin are robust to including a dummy variable for U.S. or U.K. based organization. There are at least three possible explanations for the different result. First, legal differences may be more of a constraint in developing countries (although we do not find such a result in the few developing country investments in our sample). Second, they study primarily private equity investments in more mature businesses rather than VC investments. It may be more difficult to contract around existing assets. Finally, their sample may include investors with government ties who may have different incentives from the investors we study. In our conclusion, we discuss how the findings

\footnotetext{
${ }^{3}$ See Bascha and Walz (2001) for Germany, Bengtsson and Lindström (2000) and Isaksson, Cornelius, Junghagen, and Landström (1999) for Sweden, Cumming (2000, 2001) for Canada, Lauper (2000) for Switzerland, and Hege,
} 
of a recent paper by Acemoglu and Johnson (2003) are potentially helpful in reconciling our results with those in Lerner and Schoar (2003).

Our paper also complements earlier work on global venture capital activity. In a crosscountry study, Jeng and Wells (2000) show that factors such as IPO activity, government policies toward start-ups, and labor market rigidities help explain differences in aggregate venture capital activity between countries. Similarly, Mayer, Schoors, and Yafeh (2001) argue that country differences in the composition of investors who provide funds to VC firms (banks, insurance companies, pension funds, private corporations) result in different VC portfolio characteristics across countries with respect to stage, geography, and industry focus.

The paper proceeds as follows. In section 2, we discuss the sample. In section 3 , we present our univariate analyses of the sample contracts and consider the (univariate) relation of those contracts to legal and institutional factors, as well as VC characteristics. In section 4, we present our multivariate results. In section 5, we relate the contractual terms to VC survival. In section 6 , we conclude.

\section{Sample}

\subsection{Description}

We analyze 145 investments in 107 companies in 23 countries by 70 different lead VCs. We obtained the investments from two sources - directly from VCs whom we know who invest outside the U.S. and indirectly with the help of a limited partner (institutional investor) who invests in non-U.S. VC partnerships. All of the VC partnerships were for profit, nongovernmental entities.

Palomino, and Schwienbacher (2003) for Europe. 
For each company and for each financing round for the company, we asked the VC to provide the (1) term sheet; (2) stock and security purchase agreements; (3) company's business plan; and (4) the VC's internal analysis of the investment. The amount of information we obtained differs across investments and the different VCs who provided info.

Table 1 presents summary information. Panel A organizes the observations by country and legal origin, and reports the number of financing rounds, number of companies, number of VCs, and country institutional characteristics. Investments from countries with common law, civil law, German law, and Scandinavian law origins are well-represented. In addition, we have five investments from countries of communist background.

Panel B indicates that the sample is relatively recent with all but 8 of the investment rounds were completed after 1997. In the analysis that follows, we compare the contracts in these investments to those in Kaplan and Stromberg (20003) who use a sample of U.S. investments that is roughly two years older.

Panel C presents the industry distribution of the portfolio companies in our sample. The greatest percentage of companies, $58 \%$, is in software and internet. Just over $10 \%$ of the companies are in each of hardware, telecommunications, and life sciences.

Panel D provides additional information about the investments. We have the first VC round for $89 \%$ of the companies and roughly $2 / 3$ of the investments are early stage, meaning that the companies are quite young and have a limited operating history. Finally, the average investment is between $\$ 6$ and $\$ 7$ million with a median of just over $\$ 3$ million.

\subsection{Sample selection issues}

In this section, we discuss potential selection issues concerning our sample. Our companies and financings are not a random sample in that we obtained the data from VC firms 
with whom we have a direct or indirect relationship.

It is possible that we have a bias toward the more successful investments of a particular

VC. We think this is unlikely because the investments we obtained from the VCs we contacted directly included their most recent deals while the investments we obtained with the help of the limited partner were not selected by the VCs. Even if some performance bias exists, we do not think it is likely to affect our results because we do not attempt to measure performance of individual investments. Rather, we try to characterize what contracts look like across different countries.

The more serious potential bias is that we have selected the $\mathrm{VC}$ firms. It is possible that the average VC in our sample is different from the average VC in any of the countries we study. If this is so, then our sample averages may be inaccurate. However, there is, again, no reason to believe that our results regarding cross-sectional differences across legal regimes and types of VCs are biased in any way.

Nevertheless, we acknowledge that the sample is selected and it is difficult to know the extent of any bias. We have discussed the more likely biases and do not believe there are any obvious red flags.

\section{Contract characteristics: Univariate analyses}

In this section, we present univariate analyses of the sample contracts and consider the (univariate) relation of those contracts to legal and institutional factors, as well as VC characteristics. 


\subsection{Non-U.S. versus U.S. financings}

The first two columns of table 2 describe the contracts in our sample and compare them to the U.S. contracts in Kaplan and Strömberg (2003). There is much more variation in the types of securities used outside the U.S. Whereas over $95 \%$ of the U.S. financings employed some type of convertible preferred stock, fewer than 54\% of the non-U.S. financings employed convertible preferred. Ordinary common stock is more typical outside the U.S., used in almost $28 \%$ of financings versus fewer than $1 \%$ in the U.S. Cumming (2001) and Lerner and Schoar (2003) obtain similar results. Financings outside the U.S. also make use of senior common stock $14.5 \%$ of the time. Although called "common stock," senior common stock resembles convertible preferred in that it always has a liquidation preference senior to ordinary common.

Kaplan and Strömberg (2003) show that VC financings separately allocate cash flow rights, board rights, voting rights, liquidation rights, and other control rights. Panels B to E of table 2 compare these rights in the non-U.S. sample to those in the U.S. sample of our previous paper.

Kaplan and Strömberg (2003) find that VCs use anti-dilution rights, contingencies or milestones, and vesting in order to increase the sensitivity of the founder's cash flow rights to performance, consistent with principal-agent theories. Panel B compares incentive mechanisms that affect founder cash flow rights. We find that these mechanisms - anti-dilution rights (56\% vs. $94 \%$ ), funding milestones (39\% vs. 53\%), and founder vesting (37\% vs. $44 \%)$ - are all less common outside the U.S.

Kaplan and Strömberg (2003) also show that the allocation of liquidation rights is an important feature of U.S. VC contracts. In the U.S., VC securities are almost always senior (97\% of financings) to common stock in liquidation for an amount equal to or greater than the amount invested. The seniority of the VC claim is a standard prediction of many financial 
contracting theories, such as classical moral hazard theories (Holmstrom (1979)), signaling and screening theories (Ross (1977) and Diamond (1991)), as well as the "stealing" theories of debt (Hart and Moore (1998)). Panel C indicates that VC liquidation preferences are smaller in nonU.S. financings. In $34 \%$ of the non-U.S. financings, the VC security has a liquidation preference less than the amount invested. It also is less common for non-U.S. financings to have a liquidation preference that exceeds the amount invested (48\% vs. $68 \%$ ).

Panel D compares the VC's ability to force the liquidation of its investment. Redemption rights give the VCs the ability to put their shares back to the company at some future date. When used, the rights typically provide bargaining power to force a sale. Redemption rights are present in $72 \%$ of the U.S. financings and only $34 \%$ of the non-U.S. financings. VCs can obtain similar bargaining power by including "drag-along" rights together with seniority. ${ }^{4}$ Drag-along rights force founders to sell their shares if the VCs decide to sell the company. When dragalong rights and other senior exit mechanisms are combined with redemption rights, we find that the VCs can force an exit in almost $64 \%$ of the non-U.S. financings.

Consistent with control theories (Aghion and Bolton (1992) and Dessein (2002)), Kaplan and Strömberg (2003) show that U.S. contracts allocate substantial control rights such as board seats and voting rights to the VC. Panel E shows that VCs in non-U.S. financings are less likely to obtain board control of the portfolio company (12\% vs. $25 \%)$, despite obtaining a similar percentage of board seats.

Overall, then, the first two columns of table 2 suggest the VC contracts outside the U.S. have weaker rights of all types than those in the U.S. 


\subsection{Relation to legal origin}

There is a large recent literature that studies how differences in legal origins and institutions affect various aspects of financial market activity across countries. ${ }^{5}$ Countries with civil law origins and weaker outside investor protection tend to have smaller and less liquid capital markets, more concentrated corporate ownership, lower corporate dividends, and lower valuations. A few papers also have attempted to link such factors specifically to the extent of VC activity. ${ }^{6}$

The legal system may affect the design of financial contracts in such a way that certain contractual provisions may be infeasible or more costly to enforce. In addition, the contracts may need to incorporate new protective mechanisms to make up for the legal deficiencies. We now consider how the non-U.S. contracts in our sample vary with the legal origin of the country in which the portfolio company is located. The last five columns of table 2 classify the non-U.S. contracts in our sample into one of five different legal regimes - common law, civil law, German law, Scandinavian law, and communist background. Except for communist background with only five contracts, we have at least 26 contracts in the other four legal regimes. In our discussion, we generally will not refer to the results for the communist background countries because of the small number of observations.

Table 2 shows that for most provisions, common law country contracts tend to be closer to U.S.-style than the contracts in countries with other legal origins. Common law country deals tend to make greater use of convertible preferred while Scandinavian law country deals tend to make the least use of such securities. Common law country contracts (1) include more anti-

\footnotetext{
${ }^{4}$ For an analysis of drag-along rights, see Chemla, Habib, and Ljungqvist (2003).

${ }^{5}$ See Laporta et al. (1997, 1998, and 2000), Demirguc-Kunt and Maksimovic (1998).
} 
dilution protection; (2) make greater use of vesting provisions; (3) are more likely to have a liquidation preference at least equal to the amount invested; (4) are more likely to have some type of exit mechanism; and (5) are the least likely to keep the founder in control of the board. The one exception is that the common law country deals are the least likely to use milestones.

Overall, these results suggest that legal origins / legal regimes affect the nature and types of contracts that are written. This is consistent with the evidence in the LaPorta et al. papers that countries differ in their corporate law and in the ability to write and enforce contracts

\subsection{Relation to legal, tax, and accounting institutions}

The results in the previous section indicate that legal origins matter for contracts, but do not indicate why. In this section, we consider whether seven specific measures of differences in legal rules, tax rules, accounting rules, and market institutions drive those results.

First, we consider the "rule of law" index used by LaPorta et al. (1997). The index is a measure of the quality of a country's legal and enforcement system. ${ }^{7}$ The first column of table 3 indicates that U.S. style contracts are negatively correlated with the rule of law measure. Convertible preferred, anti-dilution rights, liquidation preference, and exit provision are more common in countries with low rule of law. One might interpret this result as showing that U.S. style contracts are more appropriate when rule of law is low. There are two problems with this interpretation. First, the U.S. has the highest rule of law. Second, the results are largely driven by the fact that non-U.S. contracts are more typical in Scandinavian countries that have a high rule of law.

\footnotetext{
${ }^{6}$ See Black and Gilson (1998), Jeng and Wells (2000), and Mayer, Schoors, and Yafeh (2001)
} 
Apart from the legal system, corporate governance also may be affected by a country's accounting system (see Bushman and Smith (2001)). This is likely to be particularly true in the case of contingencies or milestones that are use accounting-based performance measures. Under a less reliable accounting system, such milestones might be less feasible, leading to fewer contingencies. In the second column of table 3 , we consider how the contracts in our sample vary with the accounting standards of the company's country, using the measure of accounting standards from LaPorta et al. (1997). The column indicates that the contracts are qualitatively identical across countries with strong and poor accounting standards.

Third, contracts may be affected by the strength of a country's bankruptcy laws and creditor protection. In particular, one might expect creditor protection to have an effect on liquidation rights. We use the index of creditor protection calculated in LaPorta et al. (1997). Column 3 of table 3 indicates that contracts in high creditor protection countries have greater liquidation rights and make greater use of exit provisions. Again, this result is somewhat difficult to interpret as U.S. contracts have strong liquidation rights, but the U.S. has the lowest creditor protection score.

Next, we consider differences in minority shareholder protection. To the extent that minority shareholders are not protected, it may be more important for the VCs to get explicit control rights. We use the index of shareholder protection calculated in LaPorta et al. (1997). Column four of table 3 indicates that there are no substantive differences across low and high minority protection countries.

Fifth, we consider restrictions on the ability of corporations to buy back their own shares.

\footnotetext{
${ }^{7}$ We assume that this measure (and other various measures we use), calculated in LaPorta et al. (1997), are still valid for our slightly later sample period.
} 
Such restrictions are potentially important in that they might make it more difficult to implement redemption and vesting provisions that typically require the company to repurchase shares. We distinguish between countries in which companies can or cannot repurchase more than ten percent of their shares (See Sabri (2002)). Column five of table 3 indicates that differences in repurchase rules are unrelated to the contract provisions in our sample.

Sixth, we consider the tax environment that firms face. One area where taxation differences might play an important role in contract design is the tax treatment of equity-based compensation (including employee stock options). The European Venture Capital Association (see EVCA (2001)) argues that the heavy taxation of stock option grants in Europe hampers the ability of investors to provide incentives to portfolio company management. The EVCA's lobbying activity has recently led several countries to change their tax rules for employee stock options to more closely resemble the U.S. treatment. ${ }^{8}$

We distinguish between countries with favorable and unfavorable taxation of stock options. We code as unfavorable those tax regimes that tax stock option gains at vesting (rather than at exercise or sale) or tax option gains at marginal tax rates that exceed $40 \%$. We might expect to see less incentive compensation and less use of vesting in countries with unfavorable taxation. Column six of table 3 indicates that the only significant difference across favorable and unfavorable tax regimes is the use of anti-dilution provisions that are not particularly related to tax. Vesting provisions are more common in favorable tax regimes, but not significantly so.

Finally, we consider the liquidity of the stock markets in the portfolio company countries. Black and Gilson (1998) argue that an active venture capital market relies heavily on the VCs' ability to exit their portfolio investments through a public offering. In support of this argument, 
Jeng and Wells (2000) find that VC investing is higher in countries with greater numbers and values of initial public offerings of stock (IPOs). We distinguish IPO activity by whether the country had more than thirty IPOs in $1999 .{ }^{9}$ We might expect the strength of exit provisions to be related to this measure. In column 7 of table 3, the only significant difference across IPO activity is that ordinary common is more prevalent in countries with high IPO activity.

Overall, then, the direct measures of legal, tax, and accounting institutions that we have explored are not particularly successful in explaining the previous results on the relation of the contracts to legal origin.

\subsection{Implementation of U.S. style contracts outside the U.S.}

The results in the previous section suggest that legal, tax, and institutional differences are unlikely to be the whole story in explaining the distribution of contracts that we observe. In this section, we explain why those results may not be surprising - some VCs manage to implement U.S. style contracts in all of the countries we study. Table 4 summarizes this discussion.

First, even if convertible preferred stock is disfavored in corporate law, it is generally possible to use senior common stock or combinations of common and non-convertible preferred stock or debt to mimic the control and liquidation rights of convertible preferred.

Second, even if the legal regime makes it difficult to impose standard anti-dilution provisions, it is generally possible to mimic those provisions using warrants that are exercisable conditional on a subsequent financing at a lower valuation.

Third, even if vesting and other contingencies are hampered by unfavorable tax laws, it is

\footnotetext{
${ }^{8}$ Also, see Keuschnigg and Nielsen (2002) for a discussion of the impact of capital gains taxation on VC activity.
} 
generally possible to use put options on the entrepreneur's stock that are exercisable by the VC if the entrepreneur leaves or misbehaves. In countries where additional equity for the entrepreneur is taxed as compensation, it is possible to provide contingent equity by making the valuation or financing contingent rather than the entrepreneur's equity stake.

Fourth, it seems unlikely that legal differences could explain the absence of liquidation preference. VCs can use seniority clauses in all of the countries in our sample.

Fifth, even if redemption rights are infeasible due to restrictions on a company buying back its own stock, the VC can mimic these rights by combining a senior claim with drag-along rights. This effectively gives the $\mathrm{VC}$ the right to liquidate because drag-along rights force all shareholders to sell when the senior claimant decides to sell even if the senior claimant gets all or most of the proceeds.

Sixth, if the local legal, tax, and institutional environment simply gets too restrictive, it is generally possible to reincorporate the company in a country that is less restrictive. As column 3 of table 1 shows, $21 \%$ of the companies in our sample do reincorporate in another country. There is a net flow of companies from countries of German and Scandinavian legal origin to countries of common law origin.

These six examples indicate that while it may not be easy or obvious how to adapt a particular contract, with enough effort and legal expertise, it appears possible to replicate most U.S. style contractual mechanisms elsewhere.

\footnotetext{
${ }^{9}$ While this is admittedly a coarse measure of IPO activity, our results are qualitatively identical using other measures, including the value of IPOs and both the number and value normalized by population or GDP.
} 


\subsection{Relation to VC experience and sophistication}

The previous section describes how some VCs are able to get around institutional constraints to implement U.S. style contracts. In this section, we examine the characteristics of those VCs who do so. For each financing, we identify the lead VC based on the VC who invests the greatest amount in that financing. The lead VC typically plays the greatest role in negotiating the contract with the entrepreneur.

In our analysis, we attempt to distinguish among the lead VCs by experience and sophistication using three different variables. First, we distinguish between smaller and larger VCs, using a breakpoint of (the sample median of) \$200 million under management. Second, we distinguish between younger and older VC firms, using a breakpoint of (the sample median age of) four years. Third, we classify VCs according to their familiarity with the U.S. 37 financings were led by VCs based in the U.S.; 87 financings were led by VCs who had previously syndicated (or invested) with U.S. VCs; and 37 financings were led by VCs with no U.S. experience. We determined if the VC had U.S. experience by examining the Venture Economics financing database, the VentureOne financing database, and the individual VC websites.

Table 5 indicates that U.S. style provisions are strongly and positively correlated with all three VC experience variables. Larger VCs, older VCs, and VCs with U.S. experience are all more likely to use convertible or participating preferred, stronger liquidation preferences, and stronger exit provisions. Older VCs and VCs with U.S. experience also use more time vesting, have stronger anti-dilution protection, and are less likely to leave the founder with board control. It is only in the use of milestones where there are no clear differences across $\mathrm{VC}$ experience.

The strong results for $\mathrm{VC}$ experience contrast with the much weaker results for legal, tax, and accounting institutions. The univariate results, therefore, seem particularly consistent with the importance of learning. The multivariate analysis in section 4 will allow us to test this. 


\subsection{Relation to financing round characteristics}

It also is possible that the contractual characteristics vary with other characteristics of the financing round. Accordingly, our final univariate analysis considers how contractual characteristics vary with the size of the investment, whether the investment is the first by a VC, and the age of the portfolio company.

Column 1 of table 6 shows that larger financing rounds (greater than $\$ 3$ million) tend to use more U.S. style contracts. Larger rounds are more likely to use convertible preferred, have stronger liquidation preferences, stronger exit provisions, and more VC board control.

Column 2 of table 6 indicates that subsequent VC rounds also make somewhat greater use of U.S. style contracts. Subsequent VC rounds are more likely to use convertible preferred, have marginally stronger liquidation preferences, and more $\mathrm{VC}$ board control.

Finally, column 3 of table 6 shows that younger portfolio companies are somewhat more likely to have U.S. style contracts. They are more likely to use convertible preferred, have stronger liquidation preferences and stronger exit provisions.

\section{Multivariate results}

At this point, we have found that VC contracts are highly related to a country's legal origin and measures of $\mathrm{VC}$ experience or sophistication. The contracts also are somewhat related to deal characteristics and legal, accounting and institutional features. In this section, we assess the relative importance of these different variables using multiple regression analyses.

We use seven different contract characteristics as dependent variables: (i) whether the round uses convertible or participating preferred; (ii) whether the round uses founder vesting; (iii) whether the round uses milestones; (iv) whether the round uses anti-dilution protection; (v) 
whether the liquidation preference is less than, equal to, or greater than the amount invested; (vi) whether the round uses redemption rights; and (vii) whether the founder has control, shares control, or does not have control of the board.

Most of the regressions measure legal origin as a dummy variable equal to one if the portfolio company is in a country with a common law legal origin. We also estimate some regressions using the indices for accounting standards, creditor protection, minority protection, and the dummy for option taxation. The reported regressions do not include share repurchase restrictions or IPO activity. When these variables are included, they are never significant.

The regressions measure $\mathrm{VC}$ sophistication using a dummy variable equal to one if the lead VC is U.S.-based, a dummy variable equal to one if the lead VC is not U.S.-based, but has previously syndicated with U.S. VCs, and a variable equal to the age (in years) of the VC firm at the time of the financing.

All of the regressions control for whether the round is the first $\mathrm{VC}$ round and portfolio company age. They do not control for round size because that is arguably endogenous with the contracts. The results are qualitatively similar when we control for round size. When the regressions control for industry and year effects, we include four dummy variables for industry (software and Internet, hardware, telecom, and life science) and four for year (1998 to 2001).

In panel A of table 7, we estimate the regressions with the common law dummy and the VC sophistication variables. These regressions do not control for industry and year effects. The regressions strongly suggest that $\mathrm{VC}$ sophistication swamps the effect of legal origin. The common law dummy is significant only for the use of anti-dilution provisions. In contrast, at least one of the VC sophistication variables is significant in all seven specifications. U.S. style contracts are significantly more likely with U.S.-based VCs for all of the specifications except for the use of milestones. U.S. style contracts also are significantly more likely for VCs who 
have syndicated with U.S. VCs in all of the specifications except the one using vesting. In addition, the use of convertible preferred, anti-dilution protection, and liquidation preferences all increase with VC age.

Panel B of table 7 estimates the same regressions as in panel A, but controls for industry and year effects. The common law origin variable is now significant in two of the regressions. Convertible preferred and anti-dilution rights are more likely in countries of common law origin. Again, however, at least one measure of VC sophistication is significant in all seven specifications. With minor exceptions, the coefficients and significance levels are unchanged.

Panel $\mathrm{C}$ of table 7 replaces the common law origin dummy with the more detailed accounting, legal, and tax variables, but, again, controls for industry and year. We lose some observations because we do not have the relevant indices for all of the countries in our sample. The accounting, legal, and tax variables are at best modestly successful in explaining the use of U.S.-style contracts. Accounting standards are significantly related to time vesting although not to milestones. Minority protection is negatively related to liquidation preferences, while creditor protection is positively related. Finally, favorable option taxation is positively related to the use of convertible preferred and vesting.

The VC sophistication results, in contrast, are qualitatively similar to those in panels A and $\mathrm{B}$, although the variables are no longer significant in the milestone specification.

Finally, in panel D of table 7, we estimate regressions including the VC sophistication variables, but excluding investments in common law countries, to determine if the VC sophistication results hold outside of common law countries. The results are qualitatively and statistically identical to those in panel C.

Overall, then, the results in table 7 indicate that the $\mathrm{VC}$ sophistication variables consistently have significant explanatory power while the legal and institutional variables do not. 


\section{The relation of contractual terms to VC survival.}

The analysis so far suggests that the most sophisticated and experienced VCs are able to implement U.S. style contracts across many different legal regimes. One interpretation of this result is that U.S. style contracts are optimal or, at least, the most effective of available contracts. This interpretation is consistent with Kaplan and Schoar (2003) who find that more experienced VCs outperform less experienced VCs. Another interpretation, however, might be that VCs use the contracts with which they are familiar. Because the more sophisticated and experienced VCs are more familiar with U.S. contracts, they use them regardless of whether they are optimal.

In this section, we attempt to distinguish between those two interpretations by looking at the ex post performance of the lead VCs in our sample. If the first interpretation is accurate, then the VCs who use U.S. style contracts should be more successful than those who do not. Under the second interpretation, we would not expect to see a large difference.

There are 70 different lead VCs in the financings in our sample. Although we cannot collect ex post return information on these VCs, we can observe whether the VC firms are still operating entities. We used Venture Economics, VentureOne, and the VC firm websites to determine the current status of the VC firms. Table 8 reports that as of August 2003, 59 of the 70 lead VCs were still active and independent while 11 had failed or had been acquired.

We then classify VCs according to whether they always used, sometimes used, or never used convertible or participating preferred stock. We take the use of such stock as indicative of using U.S. style contracts because this is true of virtually all the U.S. financings in Kaplan and Strömberg (2003).

The results are striking and highly statistically significant. Of the 29 VCs that never used a preferred stock, $34 \%$ (or 10) have not survived. Of the $37 \mathrm{VCs}$ that always used a preferred 
stock, none has failed. The four VCs who sometimes used a preferred stock fall in between with one of the four having not survived. Said another way, ten of the eleven VCs that have failed to survive never used a preferred stock.

The other two panels of the table separate VCs based in common law countries from VCs based in non-common law countries. The outcomes for VCs in non-common law countries drive the results. Still, the one failed VC firm in a common law country was one that never used a preferred stock.

Overall, then, while the survival and failure results do not prove causation, it is clear that the more successful VCs use convertible or participating preferred rather than common stock.

\section{Summary and conclusion}

In this paper, we have compared VC contracts in twenty-three other countries to those in the U.S. We have analyzed how the contracts allocate cash flow, board, liquidation, and other control rights. In univariate analyses, we find that contracts differ across legal regimes. In particular, U.S. style contracts are more typical in common law countries. However, there appear to be few institutional impediments against implementing U.S.-style terms. We find that more experienced and sophisticated VCs are able to implement U.S.-style contracts regardless of legal regime. In multivariate specifications, measures of VC sophistication and experience are more influential than legal regime or other legal, accounting, and institutional variables. Finally, we consider the subsequent survival rate of the lead VCs in our sample. VCs who use U.S.-style contracts are strikingly and significantly less likely to fail.

We think the most plausible interpretation of our results is as follows. The contracts in the U.S. have developed over several cycles and are effective. The results in Kaplan and Strömberg (2003) suggest that many elements of these U.S. contracts are consistent with the 
predictions of optimal contracting theories. Venture capital investing outside of the U.S. is relatively more recent and the legal rules are different. Learning about optimal or effective contracts takes time and effort. Even in cases where VCs would like to implement U.S. style contracts, it may not be costless to do so. If contracts were important for VC success, one would expect that over time, the more sophisticated and successful VCs would implement more effective contracts. Furthermore, one might expect the evolution to accelerate in periods of high volatility such as the bursting of the tech "bubble."

We believe the results have implications for the law and finance literature. The intuitions and predictions of financial contracting theories appear to be valid across different institutional and legal regimes. Based on this, we would expect more convergence toward U.S. style contracts in the future, particularly as financial markets become more global.

One caveat to this prediction is that our results are based on start-ups largely in developed countries. There are two forces that may favor convergence for these types of firms. First, enforcement of laws is generally not a major problem in most of the countries we study. Second, it may be easier to write desirable contracts for new businesses than for existing ones. The somewhat different results in Lerner and Schoar (2003) for private equity investments in developing countries suggest that either or both of these forces may be quite important.

In fact, our results in conjunction with those of Lerner and Schoar (2003) are remarkably consistent with the findings and conjectures in Acemoglu and Johnson (2003). Acemoglu and Johnson (2003) conjecture that:

"individuals can structure contracts to reduce the adverse effects from contracting institutions ... Because of these adjustments, the usual effect of rules governing contracts on investment and growth may be relatively limited; exceptions occur only when contracting institutions are extremely bad. In contrast, because enforceable contracts between the state and individuals are not possible, property rights institutions constraining arbitrary behavior and expropriation by the state and elites controlling the state have more important effects on economic outcomes." 
Our results suggest that sophisticated investors contract around existing contracting institutions to implement similar (optimal) contracts for (i) start-ups located in countries in which property rights are enforced; and (ii) for start-ups in developing countries with poor property right enforcement that are able to reincorporate in countries in which property rights are enforced. It may be more difficult for more mature companies in developing countries to incorporate elsewhere. 
References

Acemoglu, Daron, and Simon Johnson, 2003, “Unbundling institutions,” NBER Working Paper No. 9934.

Aghion, Phillippe, and Patrick Bolton, 1992, "An incomplete contracts approach to financial contracting", Review of Economic Studies, 77: 338-401.

Arundel, Keith, 2001, "European Venture Capital - At an All Time High,” Journal of Private Equity, Summer, 43-51.

Bascha, Andreas, and Uwe Walz, 2001, "Financing Practices in the German Venture Capital Industry: An Empirical Assessment”, working paper, University of Thübingen.

Black, Bernard and Ronald Gilson, 1998, "Venture capital and the structure of capital markets: Banks versus stock markets," Journal of Financial Economics.

Bushman, Robert, and Abbie Smith, 2001, "Financial Accounting Information and Corporate Governance", Journal of Accounting and Economics 32, 237-333.

Chemla, G., M. Habib, and A. Ljungqvist, 2003, “An analysis of shareholder agreements,” Working paper, New York University.

Cumming, Douglas, 2000, “The Convertible Preferred Equity Puzzle in Canadian Venture Capital Finance,” working paper, University of Alberta.

Cumming, Douglas, 2001, "United States Venture Capital Contracting: Evidence from Investments in Foreign Securities," working paper, University of Alberta.

Demirgüç-Kunt, Asli, and Vojislav Maksimovic, 1998, “Law, Finance, and Firm Growth,” Journal of Finance 53:6, $2107-2137$.

Ernst \& Young, 2000a, The Global Executive 2000, www.ey.com .

Ernst \& Young, 2000b, The Worldwide Corporate Tax Guide 2000, www.ey.com .

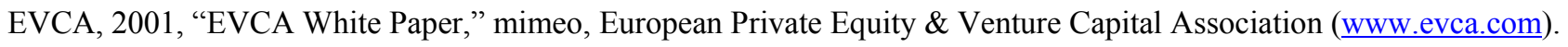

Gilson, Ronald, and Theodore Baums, 1999, "The Legal Infrastructure of the German Venture Capital Market: Replicating the U.S. Template”, working paper, Stanford Law School.

Gompers, Paul and Josh Lerner, 1999, The Venture Capital Cycle. (Cambridge, MA: MIT Press).

Hart, Oliver, 2001, “Financial Contracting”, Journal of Economic Literature 39, 1079-1100.

Hege, Ulrich, Frederic Palomino, and Armin Schwienbacher, 2003, "Determinants of venture capital performance: Europe and the United States," working paper, HEC School of Management.

Jeng, Leslie, and Philippe Wells, 2000, "The Determinants of Venture Capital Funding: Evidence Across Countries", Journal of Corporate Finance 6, 241-289.

Kaplan, Steven and A. Schoar, 2003, “Private Equity Performance: Returns, Persistence and Capital Flows,” Working Paper, University of Chicago, October 2003.

Kaplan, Steven and Per Strömberg. 2001, "Venture Capitalists As Principals: Contracting, Screening, and Monitoring," American Economic Review 91:2, 426-430.

Kaplan, Steven and Per Strömberg, 2003, "Financial Contracting Theory Meets the Real World: Evidence From Venture Capital Contracts," Review of Economic Studies 70(2), 281-316. 
Kaplan, Steven and Per Strömberg. 2004, "Contracts, Characteristics, and Actions: Evidence from Venture Capitalist Analyses" Journal of Finance, forthcoming.

Keuschnigg, Christian, and Søren Bo Nielsen, 2002, "Start-ups, Venture Capitalists, and the Capital Gains Tax”, CEPR Working Paper No. 3263.

King, R., and R. Levine, 1993. Finance and growth: Schumpeter might be right. Quarterly Journal of Economics 108, 717-738.

LaPorta, Rafael, Florencio Lopez-de-Silanes, and Andrei Shleifer, 1999, "Corporate Ownership around the World," Journal of Finance 54, 471-517.

LaPorta, Rafael, Florencio Lopez-de-Silanes, Andrei Shleifer, and Robert Vishny, 1997, "Legal Determinants of External Finance", Journal of Finance 52, 1131-1150.

LaPorta, Rafael, Florencio Lopez-de-Silanes, Andrei Shleifer, and Robert Vishny, 1998, "Law and Finance", Journal of Political Economy 106, 1113-1155.

LaPorta, Rafael, Florencio Lopez-de-Silanes, Andrei Shleifer, and Robert Vishny, 2000, "Investor Protection and Corporate Governance", Journal of Financial Economics 58, 3-27.

Lauper, Serge-Alexandre, 2000, "Structuring and Monitoring of Venture Capital Investments in Switzerland", Masters in Finance Thesis, London Business School.

Lerner, Josh and Antoinette Schoar, 2003, "Private equity in the developing world: The determinants of transaction structures," working paper, MIT.

Mayer, Colin, Koen Schoors, and Yishay Yafeh, 2001, "Sources of Funds and Investment Strategies of Venture Capital Funds: Evidence from Germany, Israel, Japan, and the UK, ” working paper, University of Oxford.

Rajan, Raghuram, and Luigi Zingales, 1998, "Financial Dependence and Growth,” American Economic Review 88, 559-586.

Sahlman, William, 1990, “The Structure and Governance of Venture Capital Organizations” Journal of Financial Economics 27, 473-521. 
Table 1

\section{Summary Information}

Summary information for 145 investments in 107 portfolio companies from 18 countries by 69 different lead VCs between 1992 and 2001. The effective tax rate on option gains includes social security tax, when applicable, and is calculated based on Ernst \& Young (2000a,b), using rules applicable on 1/1/2000. Information on legal origin, 'Rule of law', 'Accounting standards', 'Creditor protection', and 'Minority protection' ('Anti-director rights') are from LaPorta at al (1997). Number of IPOs' is the average number of IPOs in the country 1999 and 2000 from FIBV (www.fibv.com). '\$ VC funds invested per cap.' is calculated from the EVCA yearbook 2000, complemented with data from the Israeli VC associations. Data on share repurchase legislation is taken from Sabri (2002). 'Share repurchases unrestricted' refers to countries where corporations are allowed to buy back more than $10 \%$ of their shares.

\section{A.: $\quad$ Portfolio company location and country data}

\begin{tabular}{|c|c|c|c|c|c|c|c|c|c|c|c|}
\hline $\begin{array}{l}\text { Company's } \\
\text { country of } \\
\text { operations }\end{array}$ & $\begin{array}{l}\text { No. of. } \\
\text { fin. } \\
\text { rounds }\end{array}$ & $\begin{array}{l}\text { No. of } \\
\text { portf. } \\
\text { comp's } \\
\text { located }\end{array}$ & $\begin{array}{l}\text { No. of } \\
\text { comp's } \\
\text { reincorp. } \\
\text { from / to }\end{array}$ & $\begin{array}{l}\text { No. of } \\
\text { lead } \\
\text { VCs }\end{array}$ & $\begin{array}{l}\text { Rule } \\
\text { of law }\end{array}$ & $\begin{array}{l}\text { Account. } \\
\text { standard } \\
1990\end{array}$ & $\begin{array}{l}\text { Eff. tax } \\
\text { on } \\
\text { options } \\
\text { gains }\end{array}$ & $\begin{array}{l}\text { \#IPOs, } \\
\text { average } \\
1999- \\
2000\end{array}$ & $\begin{array}{l}\text { Creditor } \\
\text { protect. } \\
\text { score }\end{array}$ & $\begin{array}{l}\text { Minority } \\
\text { protect. } \\
\text { score }\end{array}$ & $\begin{array}{l}\text { Share } \\
\text { repurchase } \\
\text { unrestrict. }\end{array}$ \\
\hline US & 0 & 0 & $0 / 10$ & 13 & 10 & 71 & 0.40 & 847 & 1 & 5 & Yes. \\
\hline Hong Kong & 1 & 1 & $0 / 0$ & 0 & 8.22 & 69 & 0.15 & 64 & 4 & 5 & Yes. \\
\hline India & 4 & 4 & $1 / 0$ & 2 & 4.17 & 57 & 0 & 52 & 4 & 5 & Yes. \\
\hline Ireland & 7 & 3 & $0 / 0$ & 1 & 7.8 & 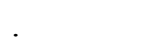 & 0.44 & 6 & 1 & 4 & No. \\
\hline Israel & 15 & 7 & $3 / 0$ & 4 & 4.82 & 64 & 0 & 28 & 4 & 3 & No. \\
\hline Singapore & 2 & 1 & $0 / 0$ & 1 & 8.57 & 78 & 0.28 & 70 & 4 & 4 & Yes. \\
\hline UK & 10 & 9 & $1 / 2$ & 9 & 8.57 & 78 & 0 & 293 & 4 & 5 & Yes. \\
\hline Common law & 39 & 25 & $5 / 15^{1}$ & 30 & & & & & & & \\
\hline Belgium & 5 & 4 & $0 / 0$ & 3 & 10 & 61 & 0 & 18 & 2 & 0 & No. \\
\hline France & 13 & 11 & $3 / 0$ & 4 & 8.98 & 69 & 0.40 & 78 & 0 & 3 & No. \\
\hline Greece & 2 & 2 & $2 / 0$ & 1 & 6.18 & 55 & . & 45 & 1 & 2 & No. \\
\hline Luxembourg & 1 & 1 & $0 / 1$ & 0 & 10 & 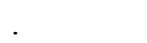 & 0.53 & 16 & . & . & \\
\hline Netherlands & 5 & 2 & $0 / 5$ & 2 & 10 & 64 & 0 & 18 & 2 & 2 & No \\
\hline Civil law & 26 & 20 & $5 / 6$ & 10 & & & & & & & \\
\hline Austria & 1 & 1 & $0 / 1$ & 1 & 10 & 54 & 0.61 & 6 & 3 & 2 & No. \\
\hline Germany & 14 & 10 & $0 / 0$ & 6 & 9.23 & 62 & 0.56 & 160 & 3 & 1 & No. \\
\hline Korea & 1 & 1 & $0 / 0$ & 0 & 5.35 & 62 & . & 10 & 3 & 2 & Yes. \\
\hline Switzerland & 27 & 20 & $5 / 0$ & 10 & 10 & 68 & 0 & 23 & 1 & 2 & Yes. \\
\hline German law & 43 & 32 & $5 / 1$ & 17 & & & & & & & \\
\hline Denmark & 3 & 2 & $1 / 0$ & 2 & 10 & 62 & 0.63 & 7 & 3 & 2 & No. \\
\hline Iceland & 1 & 1 & $1 / 0$ & 0 & 10 & & 0.10 & 9 & . & . & No. \\
\hline Norway & 3 & 1 & $1 / 0$ & 1 & 10 & 74 & 0.63 & 18 & 2 & 4 & No. \\
\hline Sweden & 23 & 21 & $2 / 0$ & 9 & 10 & 83 & 0.73 & 50 & 2 & 3 & No. \\
\hline Finland & 2 & 2 & $1 / 0$ & 0 & 10 & 77 & . & 24 & 1 & 3 & No. \\
\hline Scandin. law & 32 & 27 & $5 / 0$ & 12 & & & & & & & \\
\hline Hungary & 2 & 1 & $0 / 0$ & 0 & . & . & 0.61 & 7 & . & . & \\
\hline Czech Rep. & 1 & 1 & $1 / 0$ & 0 & . & . & . & . & . & . & \\
\hline China & 2 & 1 & $1 / 0$ & 0 & . & . & . & . & . & . & \\
\hline $\begin{array}{l}\text { Communist } \\
\text { background }\end{array}$ & 5 & 3 & $2 / 0$ & 0 & & & & & & & \\
\hline Total & 145 & 107 & $22 / 22$ & & & & & & & & \\
\hline
\end{tabular}

\footnotetext{
${ }^{1}$ Includes one company reincorporated in Bahamas and two in Bermuda.
} 


\section{B.: $\quad$ Year of VC financing:}

\begin{tabular}{|c|c|c|c|c|c|}
\hline & Pre 1998 & $\underline{1998}$ & $\underline{1999}$ & $\underline{2000}$ \\
\hline \multirow{2}{*}{\multicolumn{2}{|c|}{$\begin{array}{l}\text { First financing round for co. } \\
\text { Financing rounds in sample }\end{array}$}} & 8 & 11 & 23 & 41 \\
\hline & & 7 & 16 & 27 & 63 \\
\hline \multirow[t]{2}{*}{ C. } & \multicolumn{5}{|c|}{ Industry Distribution of Companies } \\
\hline & $\begin{array}{l}\text { Software \& } \\
\text { Internet }\end{array}$ & $\begin{array}{l}\text { Hardware \& } \\
\text { high-tech }\end{array}$ & Telecom & Life Science & Other/Unknown \\
\hline Companies & 62 & 13 & 12 & 12 & 8 \\
\hline Fin. rounds & 88 & 18 & 14 & 17 & 8 \\
\hline
\end{tabular}

\section{Other deal characteristics}

Earliest round we have for each company

$\%$ First

round inv

All financing rounds we have

$N$
$88.9 \%$

$66.9 \%$

133
Firm age, \% Early mean (med.) stage deals

$2.2(1.0)$

$2.5(1.0)$

134 $\underline{2001}$

14

31
Unknown

10

1 
Table 2

VC contract characteristics across legal regimes

Contract characteristics for 145 investments in 107 portfolio companies from 18 countries by 69 different lead VCs between 1992 and 2001. Except where noted, the numbers in the table denotes the fraction of investments in the sample exhibiting a certain contract characteristics. U.S. sample statistics are taken from Kaplan and Strömberg (2003). Contract characteristics differ significantly across sub-samples the: $1 \% * * * ; 5 \% * *$, and $10 \% *$ levels.

Contract characteristics: $\quad$ Compared to U.S.

This. US samp[e

A. Main VC security:

Convertible preferred

Ordinary common stock

Senior common stock

Convertible debt

Other security

Sample size

$\underline{\text { sample }} \underline{\text { K\&S 2003) }}$

$\begin{array}{rll}53.8 \% & 95.2 \% & 66.7 \% \\ 27.6 \% & 0.5 \% & 7.7 \% \\ 14.5 \% & 1.0 \% & 25.6 \% \\ 2.0 \% & 1.9 \% & 0.0 \% \\ 2.0 \% & 1.0 \% & 0.0 \% \\ 145 & 213 & 39\end{array}$

B. Residual cash flow rights and incentive mechanisms:

Founder stock vests over time Sample size

Equity or funding milestones Sample size

$\mathrm{VC}$ anti-dilution protection Sample size

$\begin{array}{rl}37.20 \% & 43.6 \% \\ 121 & 212 \\ 38.90 \% & 53.0 \% \\ 126 & 212 \\ 56.40 \% & 94.60 \% \\ & 213\end{array}$

Less than invested funds

Equal to invested funds

More than invested funds Cumulative dividends

Participating preferred (or equivalent)

Other "booster" (e.g. 3x)

Sample size

D. VC exit provisions:

$\mathrm{VC}$ has redemption rights

Other senior exit mechanism

No senior exit mechanism

Sample size

E. Board control

No. board seats, mean (med)

$\%$ VC board seats

Degree of board control:

Founder controls board

Neither / state-contingent $\mathrm{VC}$ controls board

Sample size

$\begin{array}{rlll}34.10 \% & 3.00 \% & 10.7 \% & 25.0 \% \\ 17.80 \% & 28.70 \% & 39.3 \% & 8.3 \% \\ 48.10 \% & 68.40 \% & 50.0 \% & 66.7 \% \\ 20.60 \% & 43.8 \% & 7.8 \% & 20.8 \% \\ 34.60 \% & 48.0 \% & 48.2 \% & 37.5 \% \\ & & & \\ 15.10 \% & 2.4 \% & 3.8 \% & 20.8 \% \\ 129 & 213 & 28 & 24\end{array}$

$\begin{array}{rl}34.5 \% & 71.8 \% \\ 50.0 \% & - \\ 36.6 \% & 28.2 \% \\ 145 & 213\end{array}$

$5.7(5.0) \quad 6.0(6.0)$

$37.0(40.0) \quad 41.4(40.0)$
$6.0(6.3)$

$32.0(33.3)$

$50.0 \%$

24

$29.6 \%$

27

$88.5 \%$

26

$\begin{array}{ll}41.0 \% & 34.6 \% \\ 66.7 \% & 63.6 \% \\ 25.6 \% & 26.9 \% \\ 39 & 26\end{array}$

$5.8(5.0)$

$40.4(40.0)$

\begin{abstract}
$18.0 \%$
$71.8 \%$

$10.3 \%$

39
\end{abstract}

$46.2 \%$
$42.3 \%$
$11.5 \%$
26

Across legal regime:

$\begin{array}{lll}\text { German } & & \underline{\text { Scandi- }} \\ & & \text { navian } \\ 48.8 \% & & 37.5 \% \\ 37.2 \% & & 50.0 \% \\ 11.6 \% & & 3.1 \% \\ 0.0 \% & & 6,2 \% \\ 2.3 \% & & 3.1 \% \\ 43 & 32\end{array}$

$46.7 \%$

30

$36.7 \%$

30

$25.8 \%$

31

$31.6 \%$
38
$42.5 \%$
40
$50.0 \%$
40

$39.0 \%$

$17.1 \%$

$43.9 \%$

$17.1 \%$

$29.3 \%$

$59.4 \%$

$9.4 \%$

$31.2 \%$

$29.0 \%$

$29.0 \%$

$19.5 \%$

41
$6.4 \%$
32

$30.2 \%$
$45.7 \%$
$39.5 \%$
43

$28.1 \%$

$28.6 \%$

$56.2 \%$

32

$\begin{array}{ll}4.8(5.0) & 5.7(5.0) \\ 42.2(33.3) & 34.3(40.0)\end{array}$

$18.6 \%$
$65.1 \%$
$16.3 \%$
43
$34.4 \%$
$56.2 \%$
$9.4 \%$
32

$6.5(7.0)^{* *}$

$38.6(34.3)$

Communist

background

$100.0 \%^{*}$
$0.0 \% \%^{* *}$
$0.0 \%$
$0.0 \%$
$0.0 \%$
5

$50.0 \%$

4

$60.0 \%$

5

$50.0 \%^{* * *}$

4

$0.0 \%$ **

$0.0 \%$ **

$100.0 \%$ **

$75.0 \%$

$25.0 \%$

$75.0 \%$

4

$60.0 \%$

$75.0 \%$

$20.0 \%$

5

$40.0 \%$

$40.0 \%$

$20.0 \%$

5 


\section{Table 3}

\section{VC contracts and other institutional characteristics}

Contract characteristics for 145 investments in 107 portfolio companies from 18 countries by 69 different lead VCs between 1992 and 2001. 'Rule of law, High' refers to the sub-sample of investments with a 'Rule of law' index of 10. 'Accounting standards, High' refers to the sub-sample of investments with an 'Accounting standards' index of 69 or higher. 'Creditor protection, High' refers to the sub-sample of investments with a 'Creditor protection' index of 3 or higher. 'Minority protection, High' refers to the subsample of investments with a 'Minority protection' index of 3 or higher. 'Favorable options tax' refers to the sub-sample of investments in countries where there is no tax on employee stock options upon exercise. 'Share repos unrestricted' refers to the sub-sample of investments in countries where corporations are allowed to buy back more than $10 \%$ of their shares. 'Per cap. VC invest.' refers to the sub-sample of investments in countries with VC investment in 1999 above $\$ 41$ per capita. 'IPO activity, High' refers to the sub-sample of investments in countries with more than 30 IPO's per year on average 1999-2000. Contractual provisions are significantly different across sub-samples at the: $1 \% * * * ; 5 \% * *$, and $10 \% *$ levels. Tests for degree of liquidation preference and degree of board control are joint across the three degrees of liquidation preference / board control, using a Kruskal-Wallis test. All other tests refer to differences in means tests, using a rank-sum test.

\begin{tabular}{|c|c|c|c|c|c|c|c|c|c|c|c|c|c|c|}
\hline \multirow[t]{2}{*}{ Contract characteristics: } & \multicolumn{2}{|c|}{ Rule of law } & \multicolumn{2}{|c|}{$\begin{array}{l}\text { Accounting } \\
\text { standards }\end{array}$} & \multicolumn{2}{|c|}{$\begin{array}{l}\text { Creditor } \\
\text { protection }\end{array}$} & \multicolumn{2}{|c|}{$\begin{array}{c}\text { Minority } \\
\text { Protection }\end{array}$} & \multicolumn{2}{|c|}{$\begin{array}{l}\text { Share repos } \\
\text { unrestricted }\end{array}$} & \multicolumn{2}{|c|}{$\begin{array}{l}\text { Favorable } \\
\text { options tax }\end{array}$} & \multicolumn{2}{|c|}{ IPO activity } \\
\hline & $\underline{\text { High }}$ & $\underline{\text { Low }}$ & High & $\underline{\text { Low }}$ & Low & $\underline{\text { High }}$ & $\underline{\text { Low }}$ & $\underline{\text { High }}$ & $\underline{\text { Yes }}$ & $\underline{\text { No }}$ & $\underline{\text { Yes }}$ & $\underline{\text { No }}$ & $\underline{\text { Low }}$ & $\underline{\text { High }}$ \\
\hline \multicolumn{15}{|l|}{ A. Main VC security: } \\
\hline Convertible preferred & 43.7 & $63.5 * *$ & 51.5 & 55.8 & 49.4 & 60.3 & 51.7 & 55.2 & 44.4 & 56.4 & 53.7 & 53.9 & 61.6 & $45.8^{*}$ \\
\hline Ordinary common & 39.4 & $16.2 * * *$ & 32.3 & 23.4 & 36.8 & $24.1 * * *$ & 29.3 & 26.4 & 33.3 & 26.6 & 20.9 & $33.3 *$ & 20.6 & $34.7 *$ \\
\hline Senior common stock & 12.7 & 16.2 & 8.8 & $19.5^{*}$ & 8.1 & $13.8 * * *$ & 17.2 & 12.6 & 22.2 & $10.6^{*}$ & 25.4 & $5.1 * * *$ & 16.4 & 12.5 \\
\hline Convertible debt & 2.8 & 1.3 & 4.4 & 0.0 & 3.5 & 0.0 & 0.0 & 3.5 & 0.0 & 3.2 & 0.0 & 3.9 & 0.0 & 4.2 \\
\hline Other security & 1.41 & 2.7 & 2.9 & 1.3 & 2.3 & 1.7 & 1.7 & 2.3 & 0.0 & 3.2 & 0.0 & 3.9 & 1.4 & 2.8 \\
\hline Sample size & 71 & 74 & 68 & 77 & 87 & 58 & 58 & 87 & & & 67 & 78 & 73 & 72 \\
\hline \multirow{2}{*}{\multicolumn{15}{|c|}{$\begin{array}{l}\text { B. Residual cash flow } \\
\text { rights and incentive } \\
\text { mechanisms: }\end{array}$}} \\
\hline & & & & & & & & & & & & & & \\
\hline$\overline{\text { Founder time vesting }}$ & 38.8 & 35.2 & 42.1 & 32.8 & 35.4 & 40.5 & 28.8 & 43.5 & 46.2 & 32.5 & 41.8 & 33.3 & 37.9 & 36.5 \\
\hline No. of obs. & 67 & 54 & 57 & 64 & 79 & 42 & 52 & 69 & 39 & 77 & 55 & 66 & 58 & 63 \\
\hline $\begin{array}{l}\text { Equity / funding } \\
\text { milestones }\end{array}$ & 35.8 & 42.4 & 41.0 & 36.9 & 37.0 & 42.2 & 41.5 & 37.0 & 43.9 & 34.2 & 33.9 & 42.9 & 39.3 & 38.5 \\
\hline No. of obs. & 67 & 59 & 61 & 65 & 81 & 45 & 53 & 73 & 39 & 77 & 56 & 70 & 61 & 65 \\
\hline $\begin{array}{l}\mathrm{VC} \text { anti-dilution } \\
\text { protection }\end{array}$ & 42.5 & $72.7 * * *$ & 52.5 & 60.0 & 50.6 & $68.3 *$ & 54.7 & 57.8 & 57.5 & 55.7 & 65.4 & $49.3 * *$ & 68.2 & 44.3 \\
\hline Sample size & 69 & 55 & 59 & 65 & 83 & 41 & 53 & 71 & 40 & 79 & 55 & 69 & 63 & 61 \\
\hline
\end{tabular}


Table 3

VC contracts and other institutional characteristics, continued.

C. Liquidation pref.:

$<$ invested funds

$=$ invested funds

$>$ invested funds

Cumulative dividends

Participating preferred

Other (e.g. 3x liquidation preference)

Sample size

D. Exit provisions:

VC redemption rights

Other senior exit

No senior exit

Sample size

\section{E. Board control}

No. seats, total, mean

(med)

$\% \mathrm{VC}$ board seats, mean

(med)

Degree of board control:

$$
\text { Founder control }
$$

Neither / state-cont.

Sample size

\section{Rule of law}

High Low

44.322 .0 **

$14.322 .0 * *$

$41.455 .9^{* *}$

$23.2 \quad 17.5$

$30.4 \quad 39.7$

$13.0 \quad 17.5$

$70 \quad 59$

$23.944 .6^{* * *}$

$41.960 .4 *$

46.527 .0 **

$71 \quad 74$

\begin{tabular}{ll}
$5.4 \quad 6.1$ \\
\hline
\end{tabular}

(5.0) (6.0)**

$6.1 \quad 5.2$

(6.0) $\quad(5.0)^{* *}$

$\begin{array}{ll}35.6 & 39.1\end{array}$

(38.8) (40.0)

\begin{tabular}{|c|c|}
\hline \multirow{2}{*}{\multicolumn{2}{|c|}{$\begin{array}{l}\text { Creditor } \\
\text { protection }\end{array}$}} \\
\hline & \\
\hline & \\
\hline & 50. \\
\hline & 52 \\
\hline & 18 \\
\hline & \\
\hline & 18 \\
\hline
\end{tabular}

Minority

Low High

$30.9 \quad 36.5$

$18.2 \quad 17.6$

$50.9 \quad 45.9$

$\begin{array}{ll}18.5 & 22.2\end{array}$

$33.3 \quad 35.6$

$22.29 .7 *$

$83 \quad 46$

$54 \quad 72$

Share repos

unrestricted

Favorable

options tax

$\underline{\text { Yes }} \underline{\text { No }}$

$34.9 \quad 35.8$

$27.9 \quad 13.6$

$37.2 \quad 50.6$

$12.2 \quad 22.5$

$31.0 \quad 36.2$

12.213 .8

$\underline{\text { Yes }}$ No

$\begin{array}{ll}24.6 & 41.7\end{array}$

$31.6 \quad 6.9$

$43.9 \quad 51.4$

$16.4 \quad 23.9$

$32.1 \quad 36.6$

$14.6 \quad 15.5$

$41 \quad 80$

$55 \quad 71$

$62 \quad 64$

$37.1 \quad 37.5$

(40.0) (38.8)

35.1
54.2

$26.446 .6^{* *}$

$43.862 .2 *$

$46.0 \quad 22.4 * * *$

$87 \quad 58$

$32.8 \quad 35.6$

$55.3 \quad 46.0$

$\begin{array}{cl}32.8 & 39.1 \\ 58 & 87\end{array}$

35.131 .1

$\begin{array}{ll}51.4 & 47.1\end{array}$

$35.6 \quad 38.3$

$45 \quad 94$

$31.3 \quad 37.2$

$52.9 \quad 47.5$

$\begin{array}{ll}32.8 & 39.7\end{array}$

$67 \quad 78$

$35.6 \quad 33.3$

$\begin{array}{ll}51.8 & 48.2\end{array}$

$32.9 \quad 40.3$

$73 \quad 72$

$\begin{array}{rl}5.7 & 5.7 \\ (5.0) & (6.0) \\ 38.0 & 35.7 \\ (40.0) & (33.3)\end{array}$

$\begin{array}{ll}5.0 & 6.1\end{array}$

(5.0) $\quad(6.0)^{* *}$

$5.4 \quad 6.1$

(5.0) (6.0)

\begin{tabular}{ll}
$5.4 \quad 5.9$ \\
\hline
\end{tabular}

$5.7 \quad 5.7$

$41.2 \quad 34.9$

$35.6 \quad 38.0$

(5.0) (6.0)*

(5.0) (5.5)

(40.0) (40.0)

(33.3) (40.0)

36.338 .1

$37.5 \quad 37.0$

(40.0) (37.5)

$$
\begin{array}{ll}
32.4 \quad 23.0 \\
\hline
\end{array}
$$

$\begin{array}{rrrl}33.8 & 22.1 & 31.0 & 22.4 \\ 55.9 & 63.6 & 55.2 & 67.2 \\ 10.3 & 14.3 & 13.8 & 10.3 \\ 68 & 77 & 87 & 58\end{array}$

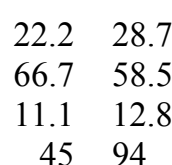

$\begin{array}{rlrl}25.4 & 29.5 & 28.8 & 26.4 \\ 61.2 & 59.0 & 57.5 & 62.5 \\ 13.4 & 11.5 & 13.7 & 11.1 \\ 67 & 78 & 73 & 72\end{array}$


Table 4

Implementation of U.S. style contracts outside the U.S.

U.S. contractual feature

Convertible preferred stock
Purpose and potential institutional obstacles

Purpose: Allocates cash-flow and control rights between $\mathrm{VC}$ and entrepreneur.

Problem: Convertible preferred stock disfavored in corporate law.

Anti-dilution rights (Full ratchet): Upon a subsequent financing at a valuation lower than the original financing, the conversion price of the original convertible preferred stock is adjusted downward to the issuance price of the dilutive financing. Written into the articles of incorporation.

Purpose: Protect VC from subsequent dilutive financing rounds.

Problem: Various, restrictions e.g. : Convertible preferred stock disfavored in corporate law; adjustment to conversion price.
Vesting Provisions: Company will have a repurchase option to buy back at cost a portion of the shares of common stock held by a certain shareholder (founder) if such shareholder's employment with the company ends before some specified date. A portion will be released each month from the repurchase option based upon continued employment.
Equity milestones: Upon company reaching a performance milestone, additional shares will be issued to founders.

Redemption provisions: (example) At the election of the holders of a majority of the preferred, the Company shall redeem the outstanding preferred shares in two equal installments beginning on the fifth anniversary of the prior preferred closing date. shareholder vote needed for

Purpose: Make it costly for founder to leave firm prematurely. Increase pay-performance sensitivity.

Problem: Vesting of shares may be treated as income, and as a result vested shares are taxed at the ordinary income tax rate upon the vesting date.

Granting / transferring of shares to founders will be treated as income, and granted shares taxed at the ordinary income tax rate.

Share repurchases restricted by corporate law.
Common + Straight preferred stock. Common + Zero-coupon debt. Senior common stock with liquidation preference. Convertible debt.

Anti-dilution warrants: Warrants attached to the VC's stock can be exercised by an investor in case of a capital increase or in case of an issuance of stock to finance the acquisition of another company, given that the price per share involved is below the original subscription price. The number of shares to be acquired this way will be such that the resulting price obtained by the investors after these transactions is equal to the original subscription price.

"Good leaver" and "bad leaver" provisions: (example)

“ 'Good leavers' (i.e founder employees voluntarily terminating their employment contract with the company) shall offer their shares in the company to the other shareholders at a price incorporating a considerable penalty.

'Bad leavers' (i.e. founders being terminated as a result of material breach by the founder employees of the applicable terms and conditions of their employment contract with the company) shall offer their shares to the other shareholders of the company at a price corresponding to the valuation of the last financing less $25 \%$. Agreement will terminate upon an IPO or a sale of the company."

Contingent valuations: Upon company reaching a performance milestone, investors will put in additional funds in the company.

Drag-along provision: After five years, if investors offer to sell their shares to a $3^{\text {rd }}$ party, it may require all the other shareholders also to sell or dispose of their shares on a pro rata basis and on the same terms to the $3^{\text {rd }}$ party. Other exit provision: If listing does not occur in five years, the parties agree that upon request of the majority of investors, the company shall instruct an investment bank to find a buyer for all of the company's shares. 


\section{Table 5}

\section{VC contract characteristics and Lead VC experience}

Contract characteristics for 145 investments in 107 portfolio companies from 18 countries by 69 different lead VCs between 1992 and 2001. The 'Lead VC' is defined as the VC committing the largest amount of funds in the syndicate in the current financing round. 'VC from US' is a dummy equal to one if the Lead VC investor is located in the United States. 'Syndicated with U.S. VC' is a dummy equal to one if the Lead VC investor is (1) not located in the United States, and (2) had either previously invested in a portfolio company located in the United States or co-invested with a U.S.-based VC at the time of the financing. 'No US exp.' is a dummy equal to one if both previous dummy variables are zero. Contractual provisions are significantly different across sub-samples at the: $1 \% * * * ; 5 \% * *$, and $10 \% *$ levels. Tests for degree of liquidation preference and degree of board control are joint across the three degrees of liquidation preference / board control, using a Kruskal-Wallis test. All other tests refer to differences in means tests, using a rank-sum test.

Lead VC funds under management

\begin{tabular}{rl}
$>\$ 200 \mathrm{M}$ & \multicolumn{1}{c}{$\leq=\$ 20$} \\
& \\
$80.8 \%$ & $26.4 \%^{* * *}$ \\
$13.7 \%$ & $41.7 \%^{* * *}$ \\
$4.1 \%$ & $25 . \%^{* * * *}$ \\
$0.0 \%$ & $4.2 \%$ \\
$1.4 \%$ & $2.8 \%$ \\
73 & 72
\end{tabular}

\section{A. Main VC security:}

Conv. / part. preferred

Ordinary common stock

Common w. liq. preference

Convertible debt

Other

Sample size

\begin{tabular}{|c|c|}
\hline \multicolumn{2}{|c|}{ Lead VC age } \\
\hline$>=4 \mathrm{yrs}$ & $\leq 4 \mathrm{yrs}$ \\
\hline $76.7 \%$ & $30.6 \% 0^{* * *}$ \\
\hline $16.4 \%$ & $38.9 \% \%^{* * *}$ \\
\hline $2.7 \%$ & $26.4 \% * * *$ \\
\hline $1.4 \%$ & $2.8 \%$ \\
\hline $2.7 \%$ & $1.4 \%$ \\
\hline 73 & 72 \\
\hline
\end{tabular}

B. Residual cash flow rights and incentive mechanisms:

Founder time vesting

Equity / funding milestones Sample size

$\mathrm{VC}$ anti-dilution protection Sample size

C. Liquidation pref.:

Less than invested funds

Equal to invested funds

More than invested funds Cumulative dividends Part. pref. (or equiv.) Other "booster" (e.g. 3x)

Sample size

D. Exit provisions:

$\mathrm{VC}$ has redemption rights Other senior exit

mechanism

No senior exit mechanism

Sample size

\section{E. Board control}

No. seats, total, mean (med)

$\% \mathrm{VC}$ board seats

Degree of board control:

Founder controls board

Neither / state-contingent $\mathrm{VC}$ controls board

No. obs.

$\begin{array}{rl}35.20 \% & 38.80 \% \\ 54 & 67 \\ 33.90 \% & 43.30 \% \\ 59 & 67 \\ 61.80 \% & 52.20 \% \\ 55 & 69\end{array}$

$\begin{array}{rl}17.2 \% & 47.9 \%^{* * *} \\ 5.2 \% & 28.2 \%^{* * *} \\ 77.6 \% & 23.9 \%^{* * *} \\ 32.1 \% & 11.4 \%^{* * *} \\ 57.9 \% & 15.7 \%^{* * *} \\ 17.9 \% & 12.9 \% \\ 58 & 71\end{array}$

$46.6 \% \quad 22.2 \% \%^{* * *}$ $55.1 \% \quad 45.9 \%$

$24.7 \% \quad 48.6 \% \%^{* * *}$

$73 \quad 72$

$\begin{array}{rl}50.9 \% & 25.0 \% \%^{* * *} \\ 57 & 64 \\ 45.90 \% & 32.30 \% \\ 61 & 65 \\ 73.3 \% & 40.6 \% \%^{* * *} \\ 60 & 64\end{array}$

$24.6 \% \quad 42.6 \%$ *** $9.8 \% \quad 25.0 \%$ \%** $65.6 \% \quad 32.4 \%$ *** $31.7 \% \quad 10.6 \%$ \%** $45.0 \% \quad 25.4 \%$ ** $23.3 \% \quad 7.6 \%$ ** 6168

$48.0 \% \quad 20.8 \% \%^{* * *}$ $48.8 \% \quad 51.7 \%$

$30.1 \% \quad 43.1 \%$ $73 \quad 72$

$\begin{array}{rl}5.9(5.5) & 5.5(5.0) \\ 40.9(40.0) & 34.0(33.3) \\ & \\ 21.90 \% & 33.30 \% \\ 65.80 \% & 54.20 \% \\ 12.30 \% & 12.50 \% \\ 73 & 72\end{array}$

Lead VC degree of U.S. experience

$\underline{\text { VC from }}$ Syndicated $\quad$ No US exp. US with US VC

$\begin{array}{rcl}94.7 \% & 62.1 \% & 10.8 \%^{* * *} \\ 0.0 \% & 18.4 \% & 64.9 \%^{* * *} \\ 0.0 \% & 18.4 \% & 13.5 \% \\ 0.0 \% & 0.0 \% & 8.1 \% \\ 5.4 \% & 1.2 \% & 2.7 \% \\ 37 & 87 & 37\end{array}$

$\begin{array}{rcl}66.7 \% & 40.3 \% & 18.8 \%^{* *} \\ 15 & 72 & 32 \\ 25.0 \% & 48.0 \% & 22.6 \%^{*} \\ 16 & 77 & 31 \\ 86.7 \% & 67.6 \% & 18.2 \%^{* * *} \\ 15 & 74 & 33\end{array}$

$\begin{array}{rcl}0.0 \% & 22.4 \% & 77.1 \%^{* * *} \\ 18.8 \% & 21.0 \% & 11.4 \%^{* * *} \\ 81.2 \% & 56.6 \% & 11.4 \%^{* * *} \\ 25.0 \% & 25.3 \% & 9.1 \%^{* *} \\ 62.5 \% & 42.1 \% & 0.0 \%^{* * *} \\ 12.5 \% & 17.3 \% & 12.1 \% \\ 16 & 76 & 35\end{array}$

$63.2 \% \quad 35.6 \% \quad 18.9 \%^{* *}$ $33.3 \% \quad 62.7 \% \quad 24.1 \% \%^{* * *}$ $21.0 \% \quad 28.7 \% \quad 64.9 \%^{* * *}$ $\begin{array}{lll}19 & 87 & 37\end{array}$

$6.1(6.0) \quad 5.3(5.0) * *$

$6.2(6.5)$

$5.6(6.0)$

$5.6(5.0)$ $39.3(40.0) \quad 35.5(33.3)$

$46.8(42.9)$

$36.6(33.3)$

$34.4(31.0) * *$

$5.3 \%$
$63.2 \%$
$31.6 \%$
19

$26.4 \%$

$63.2 \%$

$10.3 \%$

87
$37.8 \%$ **

$54.0 \% * *$

$8.1 \%$ **

37 
Table 6

\section{VC contracts and deal characteristics}

Contract characteristics for 145 investments in 107 portfolio companies from 18 countries by 69 different lead VCs between 1992 and 2001. 'Funds committed' is the total VC funds committed in the financing round, expressed in U.S. dollars. Country, deal and investor characteristics are significantly different at the: $1 \% * * * ; 5 \% * *$, and $10 \% *$ levels. Tests for degree of liquidation preference and degree of board control are joint across the three degrees of liquidation preference / board control, using a Kruskal-Wallis test. All other tests refer to differences in means tests, using a rank-sum test.

\section{A. Main VC security: \\ Conv. / part. preferred \\ Ordinary common stock \\ Common w. liq. preference \\ Convertible debt \\ Other \\ Number of observations}

B. Residual cash flow rights and incentive mechanisms:

Founder time vesting

Number of observations

Equity / funding milestones

Number of observations

VC anti-dilution protection

Number of observations

C. Liquidation pref.:

Less than invested funds

Equal to invested funds

More than invested funds

Cumulative dividends Part. preferred (or equiv.) Other "booster" (e.g. 3x)

Sample size

\section{Exit provisions:}

$\mathrm{VC}$ has redemption rights Other senior exit

mechanism

No senior exit mechanism

Sample size

\section{E. Board control}

No. seats, total, mean (med)

$\% \mathrm{VC}$ board seats

Degree of board control:

Founder controls board

Neither / state-contingent

Sample size $\mathrm{VC}$ controls board
Funds committed

\begin{tabular}{rl}
$>\$ 3 \mathrm{M}$ & $\leq \$ 3 \mathrm{M}$ \\
\hline $68.2 \%$ & $31.6 \%^{* * *}$ \\
$21.6 \%$ & $36.8 \% \%^{* *}$ \\
$9.1 \%$ & $22.8 \% \%^{* *}$ \\
$0.0 \%$ & $5.3 \%$ \\
$1.1 \%$ & $3.5 \%$ \\
88 & 57
\end{tabular}

$40.0 \% \quad 33.3 \%$

$70 \quad 51$

$\begin{array}{rl}43.1 \% & 33.3 \% \\ 72 & 54\end{array}$

$62.0 \% \quad 49.1 \%$

7153

$26.7 \% \quad 44.4 \%^{* *}$

$16.0 \% \quad 20.4 \%$ **

$57.3 \% \quad 35.2 \%$ **

$23.6 \% \quad 15.7 \%$

$39.7 \% \quad 27.8 \%$

$19.4 \% \quad 9.3 \%$

$75 \quad 54$

$43.2 \% \quad 21.0 \% \%^{* * *}$

$51.6 \% \quad 47.9 \%$

$30.7 \% \quad 45.6 \%$ *

$88 \quad 57$

$6.0(6.0) \quad 5.2(5.0)$ **

$40.2(40.0) \quad 33.5(33.3) * *$

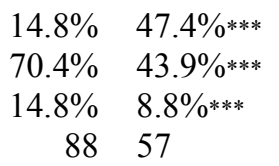

$88 \quad 57$
First VC investment?

First round Subs. round

$44.9 \% \quad 77.3 \%$ ***

$31.5 \% \quad 11.4 \%^{* *}$

$18.0 \% \quad 11.4 \%$

$3.4 \% \quad 0.0 \%$

$2.3 \% \quad 0.0 \%$

$89 \quad 44$
$39.0 \% \quad 34.4 \%$
$77 \quad 32$

$39.0 \% \quad 29.0 \%$

$77 \quad 38$

$52.0 \% \quad 69.4 \% *$

$77 \quad 36$

$37.0 \% \quad 16.7 \%$ *

$17.3 \% \quad 22.2 \% *$

$45.7 \% \quad 61.1 \% *$

$22.5 \% \quad 11.4 \%$

$32.5 \% \quad 44.4 \%$

$15.0 \% \quad 17.0 \%$

8136

$32.6 \% \quad 38.6 \%$

$47.9 \% \quad 56.7 \%$

$38.2 \% \quad 29.6 \%$

8944

$5.5(5.0) \quad 5.9(6.0)$

$35.6(33.3) \quad 41.2(40.0)^{* *}$

$\begin{array}{rl}32.6 \% & 18.2 \%^{* *} \\ 59.6 \% & 59.1 \%^{* *} \\ 7.9 \% & 22.7 \%^{* *} \\ 89 & 44\end{array}$
Firm age

$\begin{array}{rll}\leq 2 \text { years } & >=2 \text { years } \\ & 40.0 \% \%^{* *} \\ 23.2 \% & 36.0 \% \\ 11.6 \% & 20.0 \% \\ 2.1 \% & 2.0 \% \\ 2.1 \% & 2.0 \% \\ 95 & 50\end{array}$

$42.1 \% \quad 28.9 \%$

$76 \quad 45$

$37.5 \% \quad 41.3 \%$

$80 \quad 46$

$56.4 \% \quad 56.5 \%$

$78 \quad 46$

$\begin{array}{rl}29.3 \% & 42.6 \%^{* *} \\ 15.8 \% & 21.3 \%^{* *} \\ 54.9 \% & 36.2 \%^{* *} \\ & \\ 24.4 \% & 18.5 \%^{*} \\ 21.7 \% & 42.0 \%^{* *} \\ 9.9 \% & 24.4 \%^{* *} \\ 82 & 47\end{array}$

$34.7 \% \quad 34.0 \%$

$55.1 \% \quad 41.5 \%$

$32.6 \% \quad 44.0 \%$

$95 \quad 50$
$5.8(6.0) \quad 5.5(5.0)$

$32.7(35.4) \quad 39.8(40.0) *$ 


\section{Table 7}

\section{Multivariate analysis}

Summary information for 145 investments in 107 portfolio companies from 18 countries by 69 different lead VCs between 1992 and 2001 . 'First VC round' is a dummy equal to one if the investment refers to the first round where any VC invested. 'Age of firm' is the age of the portfolio company at the time of the investment, in years. 'Common law' is a dummy equal to one if the portfolio company is located in a country with a common law legal system. 'Lead VC has US experience' is a dummy equal to one if the lead VC has previously invested in a company with US-based VC funds as co-investors. 'VC is based in the US' is a dummy equal to one if the Lead VC investor is located in the United States. 'Non-U.S. VC with U.S. exper' is a dummy equal to one if the Lead VC investor is (1) not located in the United States, and (2) had either previously invested in a portfolio company located in the United States or co-invested with a U.S.-based VC at the time of the financing. 'VC age' is the age of the VC firm in years. 'Accounting standards', 'Creditor protection', and 'Minority protection' ('Anti-director rights') are from LaPorta at al (1997). 'Option tax favorable' is a dummy taking the value of one if employee and management stock options are not taxed at the point of exercise. Industry effects include dummies for 5 industries: Internet/Software, High-tech/Hardware, Telecom, Medical, Other. Regression coefficients are significantly different from zero at the $1 \% * * * ; 5 \% * *$, and $10 \% *$ levels.

\begin{tabular}{|c|c|c|c|c|c|c|c|c|c|c|c|c|c|c|}
\hline \multirow{3}{*}{$\begin{array}{l}\text { A. No industry and year effects:: } \\
\text { Constant }\end{array}$} & \multicolumn{2}{|c|}{$\begin{array}{l}\text { Deal uses conv. } \\
\text { pref. (probit) }\end{array}$} & \multicolumn{2}{|c|}{$\begin{array}{l}\text { Vesting } \\
\text { (probit) }\end{array}$} & \multicolumn{2}{|c|}{$\begin{array}{l}\text { Milestones } \\
\text { (probit) }\end{array}$} & \multicolumn{2}{|c|}{$\begin{array}{l}\text { Anti-dilution } \\
\text { (probit) }\end{array}$} & \multicolumn{2}{|c|}{$\begin{array}{l}\text { Liquidation pref. } \\
\text { (ord. probit) }\end{array}$} & \multirow{2}{*}{\multicolumn{2}{|c|}{$\begin{array}{l}\text { Redemption } \\
\text { rights (probit) }\end{array}$}} & \multicolumn{2}{|c|}{$\begin{array}{l}\text { Board control } \\
\text { (ord. probit) }\end{array}$} \\
\hline & & & & & & & & & & & & & & \\
\hline & -0.28 & $(0.40)^{* * *}$ & -0.64 & $(0.38)^{*}$ & -0.94 & $(0.41)^{* *}$ & -0.67 & $(0.37)$ & & & -0.45 & $(0.35)$ & & \\
\hline First $\mathrm{VC}$ round & -1.52 & $(0.39)^{* * *}$ & 0.13 & $(0.30)$ & 0.29 & $(0.29)$ & -0.41 & $(0.30)$ & -0.46 & $(0.28) *$ & -0.22 & $(0.26)$ & -0.73 & $(0.24)^{* * *}$ \\
\hline Age of firm & -0.23 & $(0.07)$ & -0.10 & $(0.05) * *$ & -0.03 & $(0.03)$ & -0.01 & $(0.03)$ & -0.05 & $(0.03)^{*}$ & -0.09 & $(0.03)^{* *}$ & -0.06 & $(0.03)^{* *}$ \\
\hline Common law & 0.57 & $(0.37)$ & 0.47 & $(0.34)$ & -0.38 & $(0.31)$ & 1.03 & $(0.40)^{* * *}$ & 0.14 & $(0.32)$ & -0.04 & $(0.28)$ & -0.06 & $(0.25)$ \\
\hline $\mathrm{VC}$ is based in US & 2.18 & $(0.70) * * *$ & 1.09 & $(0.47)^{* *}$ & 0.23 & $(0.48)$ & 1.49 & $(0.54) * * *$ & 1.70 & $(0.49) * * *$ & 1.17 & $(0.43)^{* * *}$ & 1.23 & $(0.40)^{* * *}$ \\
\hline Non-U.S. VC with U.S. exper. & 1.19 & $(0.42) * * *$ & 0.47 & $(0.37)$ & 0.80 & $(0.35)^{* *}$ & 0.86 & $(0.37) * *$ & 1.20 & $(0.33)^{* * *}$ & 0.55 & $(0.33)^{*}$ & 0.50 & $(0.28)^{*}$ \\
\hline $\mathrm{VC}$ age & 0.13 & $(0.03)^{* * *}$ & -0.01 & $(0.02)$ & 0.00 & $(0.02)$ & 0.04 & $(0.02)^{* *}$ & 0.05 & $(0.02)^{* *}$ & -0.02 & $(0.01)$ & -0.01 & $(0.01)$ \\
\hline Industry and year effects & No & & No & & No & & No & & No & & No & & No & \\
\hline Pseudo $\mathrm{R}^{2}$ & 0.52 & & 0.11 & & 0.07 & & 0.26 & & 0.21 & & 0.08 & & 0.11 & \\
\hline No .of obs. & 124 & & 102 & & 108 & & 106 & & 110 & & 124 & & 124 & \\
\hline \multicolumn{15}{|l|}{ B. Industry \& year controls: } \\
\hline First VC round & -2.27 & $(0.65)^{* * *}$ & 0.07 & $(0.33)$ & 0.45 & $(0.32)$ & -0.39 & $(0.32)$ & -0.51 & $(0.31)^{*}$ & -0.44 & $(0.31)$ & -0.71 & $(0.26)^{* * *}$ \\
\hline Age of firm & -0.40 & $(0.13)^{* * *}$ & -0.11 & $(0.05)^{* *}$ & -0.03 & $(0.04)$ & 0.00 & $(0.04)$ & -0.05 & $(0.03)$ & -0.14 & $(0.05) * *$ & -0.07 & $(0.03)^{* *}$ \\
\hline Common law & 0.97 & $(0.49)^{* *}$ & 0.21 & $(0.41)$ & -0.24 & $(0.34)$ & 1.10 & $(0.46)^{* *}$ & 0.31 & $(0.35)$ & -0.20 & $(0.33)$ & 0.03 & $(0.28)$ \\
\hline $\mathrm{VC}$ is based in US & 3.53 & $(0.78)^{* * *}$ & 1.49 & $(0.51)^{* * *}$ & 0.27 & $(0.55)$ & 1.62 & $(0.64) * *$ & 1.74 & $(0.54)^{* * *}$ & 1.46 & $(0.49)^{* * *}$ & 1.13 & $(0.43)^{* * *}$ \\
\hline Non-U.S. VC with U.S. exper. & 2.01 & $(0.59)^{* * *}$ & 0.77 & $(0.40)^{*}$ & 0.86 & $(0.42) * *$ & 0.82 & $(0.42) * *$ & 1.12 & $(0.36) * * *$ & 0.88 & $(0.39)^{* *}$ & 0.47 & $(0.31)$ \\
\hline $\mathrm{VC}$ age & 0.14 & $(0.04)^{* * *}$ & -0.01 & $(0.02)$ & -0.01 & $(0.02)$ & 0.04 & $(0.02) * *$ & 0.06 & $(0.02)^{* * *}$ & -0.03 & $(0.01)^{*}$ & -0.01 & $(0.01)$ \\
\hline Industry \& year effects & Yes & & Yes & & Yes & & Yes & & Yes & & Yes & & Yes & \\
\hline Pseudo $\mathrm{R}^{2}$ & 0.62 & & 0.17 & & 0.13 & & 0.31 & & 0.25 & & 0.18 & & 0.14 & \\
\hline No .of obs. & 124 & & 102 & & 108 & & 106 & & 110 & & 124 & & 124 & \\
\hline
\end{tabular}


Table 7

Multivariate analysis, continued.

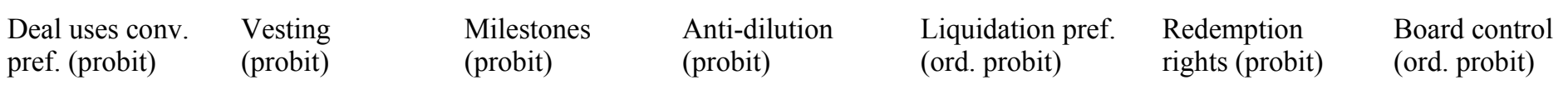

C. Specific institutional controls:

\begin{tabular}{|c|c|c|c|c|c|c|c|c|c|c|c|c|c|c|}
\hline First VC round & -2.11 & $(0.51) * * *$ & -0.11 & $(0.38)$ & 0.42 & $(0.35)$ & -0.58 & $(0.38)$ & -0.34 & $(0.34)$ & -0.47 & $(0.35)$ & -0.70 & $(0.28)^{* *}$ \\
\hline Age of firm & -0.51 & $(0.15) * * *$ & -0.19 & $(0.07) * *$ & -0.03 & $(0.04)$ & 0.00 & $(0.04)$ & -0.04 & $(0.03)$ & -0.18 & $(0.08)^{* *}$ & -0.07 & $(0.04)^{* *}$ \\
\hline Accounting standards & -0.02 & $(0.02)$ & 0.07 & $(0.03) * *$ & -0.03 & $(0.02)$ & -0.04 & $(0.03)$ & 0.02 & $(0.02)$ & -0.03 & $(0.02)$ & -0.03 & $(0.02)$ \\
\hline Creditor protection & 0.26 & $(0.16)$ & 0.12 & $(0.13)$ & -0.09 & $(0.12)$ & 0.06 & $(0.13)$ & 0.37 & $(0.13)^{* * *}$ & -0.02 & $(0.12)$ & -0.06 & $(0.10)$ \\
\hline Minority protection & 0.11 & $(0.18)$ & 0.02 & $(0.15)$ & 0.15 & $(0.14)$ & 0.06 & $(0.16)$ & -0.35 & $(0.14)^{* *}$ & 0.12 & $(0.13)$ & -0.01 & $(0.12)$ \\
\hline Option taxation favorable & 0.75 & $(0.41)^{*}$ & 0.80 & $(0.38)^{* *}$ & -0.08 & $(0.34)$ & 0.56 & $(0.37)$ & -0.04 & $(0.33)$ & -0.37 & $(0.32)$ & 0.22 & $(0.28)$ \\
\hline VC is based in US & 2.77 & $(0.78) * * *$ & 1.05 & $(0.57) *$ & 0.48 & $(0.58)$ & 1.71 & $(0.61) * * *$ & 2.20 & $(0.61) * * *$ & 1.07 & $(0.53)^{* *}$ & 1.24 & $(0.47)^{* * *}$ \\
\hline Non-U.S. VC with U.S. exper. & 1.60 & $(0.55) * * *$ & 1.09 & $(0.40) * * *$ & 0.63 & $(0.41)$ & 1.01 & $(0.42) * * *$ & 1.42 & $(0.40) * * *$ & 0.59 & $(0.40)$ & 0.53 & $(0.32) *$ \\
\hline VC age & 0.18 & $(0.05) * * *$ & 0.00 & $(0.02)$ & -0.01 & $(0.02)$ & 0.05 & $(0.02) * *$ & 0.05 & $(0.03)^{* *}$ & -0.01 & $(0.02)$ & -0.01 & $(0.02)$ \\
\hline Industry \& year effects & Yes & & Yes & & Yes & & Yes & & Yes & & Yes & & Yes & \\
\hline Pseudo $\mathrm{R}^{2}$ & 0.61 & & 0.26 & & 0.12 & & 0.29 & & 0.29 & & 0.20 & & 0.16 & \\
\hline No .of obs. & 110 & & 93 & & 96 & & 94 & & 99 & & 110 & & 110 & \\
\hline \multicolumn{15}{|l|}{ D. Excluding common law } \\
\hline \multicolumn{15}{|l|}{ countries: } \\
\hline First VC round & -1.70 & $(0.68) * *$ & 0.00 & $(0.41)$ & 0.53 & $(0.37)$ & -0.37 & $(0.39)$ & -0.46 & $(0.37)$ & -0.14 & $(0.39)$ & -0.57 & $(0.32) *$ \\
\hline Age of firm & -0.23 & $(0.10) * *$ & -0.14 & $(0.12)$ & 0.03 & $(0.07)$ & -0.16 & $(0.07)^{* *}$ & -0.14 & $(0.08) *$ & -0.10 & $(0.06)$ & 0.04 & $(0.06)$ \\
\hline $\mathrm{VC}$ is based in US & 3.76 & $(0.97)^{* * *}$ & 1.81 & $(0.69) * * *$ & 0.33 & $(0.58)$ & 1.15 & $(0.61) *$ & 1.73 & $(0.61)^{* * *}$ & 1.72 & $(0.56)^{* * *}$ & 1.11 & $(0.48)^{* *}$ \\
\hline Non-U.S. VC with U.S. exper. & 2.21 & $(0.81)^{* * *}$ & 0.91 & $(0.50) *$ & 0.60 & $(0.46)$ & 0.79 & $(0.45) *$ & 1.12 & $(0.39)^{* * *}$ & 1.00 & $(0.47)^{* *}$ & 0.70 & $(0.35)^{* *}$ \\
\hline VC age & 0.12 & $(0.03) * * *$ & 0.01 & $(0.02)$ & 0.01 & $(0.02)$ & 0.04 & $(0.02) *$ & 0.04 & $(0.02)$ & -0.01 & $(0.02)$ & -0.02 & $(0.02)$ \\
\hline Industry \& year effects & Yes & & Yes & & Yes & & Yes & & Yes & & Yes & & Yes & \\
\hline Pseudo $\mathrm{R}^{2}$ & 0.58 & & 0.22 & & 0.14 & & 0.31 & & 0.25 & & 0.18 & & 0.11 & \\
\hline No .of obs. & 88 & & 79 & & 81 & & 80 & & 83 & & 88 & & 88 & \\
\hline
\end{tabular}




\section{Table 8}

\section{Lead VC contracts and survival}

Survival and failure statistics for 70 lead VCs from 18 countries making investments between 1992 and 2001 . Failure rate is the percentage of the VC funds that had closed down or been acquired by August 1, 2003. Survival and failure status was determined from Venture Economics, VentureOne, and VC firm websites. Preferred stock represents the use of convertible or participating preferred stock. Chi square tests of difference in failure rates are significantly different at the $1 \% * * * ; 5 \% *$, and $10 \% *$ levels.

Number of Lead VCs Number of VCs failed or in sample no longer independent by August 12003

\section{$\underline{\text { Across all legal regimes }}$}

All Lead VCs

VCs always using preferred VCs sometimes using preferred

VCs never using preferred

Chi square test $(2 \mathrm{df})=14.87 * * *$

$\underline{\text { Non-common law VCs only }}$

All Lead VCs

VCs using all preferred

VCs sometimes using preferred

VCs never using preferred

Chi square test $(2 \mathrm{df})=7.23 * *$

\section{Common law VCs only}

All Lead VCs

VCs using all preferred

VCs sometimes using preferred

VCs never using preferred

Chi square test $(2 \mathrm{df})=4.14$ 